\title{
EVALUATING SEDIMENT STORAGE DAMS: STRUCTURAL OFF-SITE SEDIMENT TRAPPING MEASURES IN NORTHWEST ETHIOPIA
}

\author{
M. MEKONNEN ${ }^{1,2}$, S.D. KEESSTRA ${ }^{1}$, J.E. BAARTMAN ${ }^{1}$, \\ C.J. RITSEMA ${ }^{1}$, A.M. MELESSE ${ }^{3}$
}

\begin{abstract}
${ }^{1}$ Soil Physics and Land Management Group, Wageningen University, PO Box 47, 6700 AA Wageningen, the Netherlands.

${ }^{2}$ Amhara National Regional State, Bureau of Agriculture, PO Box 1188, Bahir Dar, Ethiopia. ${ }^{3}$ Department of Earth \& Environment, ECS 339 Florida International University, 11200 SW 8th Street, Miami.
\end{abstract}

\begin{abstract}
Reservoir and lake sedimentation is a vital problem in Ethiopia. Constructing small and medium size dams at the outlets of sub-catchments within a larger catchment helps to reduce the transport of sediment downstream to reservoirs or lakes. This study assessed the sediment trapping efficacy (STE) of sediment storage dams (SSDs) built at the outlets of eight small sub-catchments in northwest Ethiopia, as an off-site sediment trapping measure. Satellite imagery and topographic maps were used to assess land use-land cover and delineate the boundaries of sub-catchments. In the field, trapped sediment by SSDs was measured directly, as well as in- and outflow of suspended sediment with which the STE of each SSD was estimated. Sediment yield of each sub-catchment was calculated from the measured trapped sediment and estimated suspended sediment loss. Results show that SSDs trapped an average of $1584 t y^{-1}$ of the inflow sediment and catchment specific sediment yield ranged from 8.6-55 $\mathrm{t}$ ha $\mathrm{h}^{-1}$ $y r^{-1}$. Two representative SSDs constructed from gabion and stone were evaluated with regard to their STE. Results showed that their efficacy was $74 \%$ and $67 \%$ for the gabion and stone SSD, respectively. In general, although SSDs might be costly for small scale farmers and have a relatively short life span depending on their size, they are promising off-site structural measures to trap significant amounts of sediment at the outlets of sub-catchments and subsequently reduce sediment movement to downstream water bodies.
\end{abstract}

Evaluación de presas de retención de sedimento: medidas estructurales de control del transporte de sedimento en el noroeste de Etiopía

RESUMEN. La sedimentación en embalses y lagos es un problema clave en Etiopía. La construcción de presas de pequeño y mediano tamaño en la desembocadura de subcuencas dentro de cuencas más amplias ayuda a reducir el transporte 
de sedimento hacia embalses o lagos. Este estudio comprueba la eficacia en la captación de sedimento por parte de presas de retención de sedimento construidas en la desembocadura de ocho pequeñas subcuencas en el noroeste de Etiopía, como una medida de captación de sedimento. Se utilizaron imágenes de satélite y mapas topográficos para estudiar la cubierta vegetal y los usos del suelo, y para delinear los límites de las subcuencas. En el campo se midió directamente el sedimento atrapado por las presas, así como las entradas y salidas de sedimento en suspensión con el que se calculó la eficiencia de captación de sedimento por parte de cada presa. La producción de sedimento de cada subcuenca se calculó a partir del sedimento atrapado y de la estimación de pérdida de sedimento en suspensión. Los resultados muestran que las presas de retención de sedimento atrapan un promedio de 1584 $t$ año-1 de sedimento, y la producción específica de sedimento oscila entre 8.6 y 55 t ha $a^{-1} a \tilde{n} o^{-1}$. Dos presas de retención de sedimento construidas con gaviones y piedras se evaluaron en relación con su eficacia para la captación de sedimento. Los resultados demuestran que su eficacia fue del $74 \%$ y del $67 \%$ para presas de gavión y piedras, respectivamente. En general, aunque las presas son costosas para los pequeños granjeros y tienen una relativamente corta vida dependiendo de su tamaño, constituyen prometedoras medidas estructurales para atrapar significativas cantidades de sedimento en la desembocadura de pequeñas subcuencas y reducir el movimiento de sedimento hacia aguas abajo.

Key words: sediment storage dams, sediment trapping efficacy, off-site sediment trapping measures, sediment yield, Ethiopia.

Palabras clave: presas de almacenamiento de sedimento, eficacia en la captación de sedimento, medidas de captación de sedimento, producción de sedimento, Etiopía.

Received 7 November 2014 Accepted 27 January 2015

*Corresponding author: Soil Physics and Land Management Group, Wageningen University, PO Box 47, 6700 AA. Wageningen, the Netherlands. E-mail: Mulatie.getahun@wur.nl; mulatiemekonneng@gmail.com

\section{Introduction}

On-site soil erosion and off-site sedimentation are natural phenomena in landscape formation. However, human activities have accelerated natural erosion rates causing onand off-site problems with soil degradation and sediment accumulation on undesirable locations (reservoirs, rivers, etc.) (Zeleke, 2000; Morgan, 2005; Amsalu et al., 2007; Mekonnen and Melesse, 2011). Human induced off-site sedimentation is the product of on-site soil erosion resulting either from point sources like mining and construction sites or non-point sources such as from agricultural areas and grazing lands. Gully and river bank erosion are also important sources of sediment (Wasson et al., 2002; Ritsema, 2003; Keesstra et al., 2009b; Hughes and Prosser, 2012). 
In Ethiopia, the rates of soil erosion are alarmingly high and sedimentation in reservoirs, lakes, and rivers is a serious problem (Haregeweyn et al., 2006; Tamene et al., 2006a). Many reservoirs which have been established for hydroelectric power, urban water supply and irrigation accumulate large amounts of sediment, resulting in shortage of water supply for these functions, decline in reservoirs water storage capacity and high costs to remove sediment from reservoirs. Some of the dams in the Amhara region of Ethiopia, like the dams of Adrako, Borkena and Dana (Amare, 2005; Kebede, 2012) have completely silted up before their design expectation period. Other dams in this region that have been constructed over the last decades are threatened by accelerated sedimentation.

Until recently, most studies and development activities that aim at reducing the sediment load in the reservoirs were focused on on-site soil and water conservation (SWC) measures on agricultural areas in the catchment. However, SWC measures are not designed to eliminate sediment loss and transport completely. In the northern part of Ethiopia, SWC measures such as stone bunds and ex-closures trapped about $74 \%$ of the total soil eroded (Nyssen et al., 2008). A structural measure, Fanyajuu, trapped about $64 \%$ of the eroded soil at Debre Mewi watershed, northwest Ethiopia (Fisseha et al., 2011). Although on-site soil conservation measures result in reduced catchment sediment yields, sediment trapped by dams at the outlets of sub-catchments represent the dominant cause of reduced catchment sediment yields (Walling, 2006).

According to Mekonnen et al. (2014), integrating on-site sediment trapping measures with off-site measures is vital to retain sediments within sub-catchments and to reduce downstream reservoir and lake sedimentation. Streamside management, shrub and tree buffers, ponds, flood plains and check dams are widely used off-site sediment trapping measures and their sediment trapping efficacies (STE) were evaluated in various studies. For example, Lakel et al. (2010) and Ward and Jackson (2004) evaluated the STE of streamside managements. The STE of shrub and tree buffers were evaluated by Borin et al. (2005), Schoonover et al. (2006), Leguédois et al. (2008), Knight et al. (2010), Zhang et al. (2010) and Burylo et al. (2012); that of ponds by Verstraeten and Poesen (2000), Fiener et al. (2005), McCaleb and McLaughlin (2008) and Markle (2009); that of floodplains by Keesstra (2007) and Middelkoop et al. (2010); and the STE of check dams by Sougnez et al. (2011), Wang et al. (2011) and Abedini et al. (2012).

One possible way to trap sediment in the sediment cascade is using sediment storage dams (SSDs) (MERET, 2008). SSDs are physical structures or barriers built of stone or gabion at the outlets of catchments with the objective to trap sediment. SSDs have similar functions as check dams, i.e. to trap sediment except that they are mostly constructed at the outlets of larger catchments than check dams. These dams have been implemented by the Ethiopian government in the Amhara region over the last decade (MERET, 2008). Although the SSDs have been used to trap sediment as off-site SWC measure, their efficacy in trapping sediment is not well known. Hence, to assess the functioning and effectiveness of this type of measure this study aims to (1) quantify the amount of sediment trapped by SSDs and determine sub-catchment sediment yield, (2) estimate the sediment trapping efficacy (STE) of SSDs constructed at the outlets of small sub-catchments, and (3) assess the costs required to construct the SSDs and its applicability for small scale farmers, in northwest Ethiopia. 


\section{Materials and methods}

\subsection{Study area description}

The study was conducted in Amhara Regional State, northwest Ethiopia. Eight SSDs constructed at the outlets of the small sub-catchments Shehena Borkena, Enchet Kab, Worka Wotu, Woybila, Segno Gebeya, Tigrie Mender, Dodota and Wuha Chale were studied (Fig. 1). The size of the sub-catchments ranged from 34.6-104.5 ha. Table 1 summarizes the location, average annual rainfall, soil type (WBISPP, 2002), average slope and elevation characteristics of each study site. Farmland is the dominant land use type in each sub-catchment amounting to about $80 \%$ while about $20 \%$ is used as grazing land, eucalyptus plantation and/or bush land. The slopes in the sub-catchments ranged from $0.4-31 \%$ with dominant average slopes of $11.6-24 \%$.

Table 1. Location, soil type, rainfall, slope and elevation characteristics of the studied sub-catchments.

\begin{tabular}{|l|c|c|l|c|c|c|}
\hline \multicolumn{1}{|c|}{$\begin{array}{c}\text { Study } \\
\text { sites }\end{array}$} & $\begin{array}{c}\mathbf{X} \\
\text { coordinate } \\
(\mathbf{m})\end{array}$ & $\begin{array}{c}\text { Y } \\
\text { coordinate } \\
(\mathbf{m})\end{array}$ & $\begin{array}{c}\text { Soil } \\
\text { type }\end{array}$ & $\begin{array}{c}\text { Average } \\
\text { slope } \\
(\boldsymbol{\%})\end{array}$ & $\begin{array}{c}\text { Av. } \\
\text { Annual } \\
\text { rainfall }(\mathbf{m m})\end{array}$ & $\begin{array}{c}\text { Elevation } \\
\text { range } \\
(\mathbf{m} \text { a.s.l.) })\end{array}$ \\
\hline S. Gebeya & 410030 & 1204435 & Nitosols & 12.7 & 1200 & $2653-2754$ \\
\hline Woybila & 410018 & 1206409 & Nitosols & 16.4 & 1200 & $2675-2846$ \\
\hline S. Borkena & 584808 & 1209121 & Cambisol & 24.0 & 850 & $1508-1872$ \\
\hline T. Mender & 533579 & 1330784 & Cambisol & 23.9 & 870 & $2960-3094$ \\
\hline Worka Wotu & 531127 & 1329944 & Cambisol & 11.7 & 870 & $2822-2895$ \\
\hline Dodota & 607310 & 1238353 & Cambisol & 11.6 & 800 & $1621-1762$ \\
\hline Enchet Kab & 402452 & 1449577 & Leptosol & 11.9 & 1200 & $3088-3171$ \\
\hline Wuha Chale & 591772 & 1259992 & Regosol & 23.7 & 900 & $1989-2174$ \\
\hline
\end{tabular}

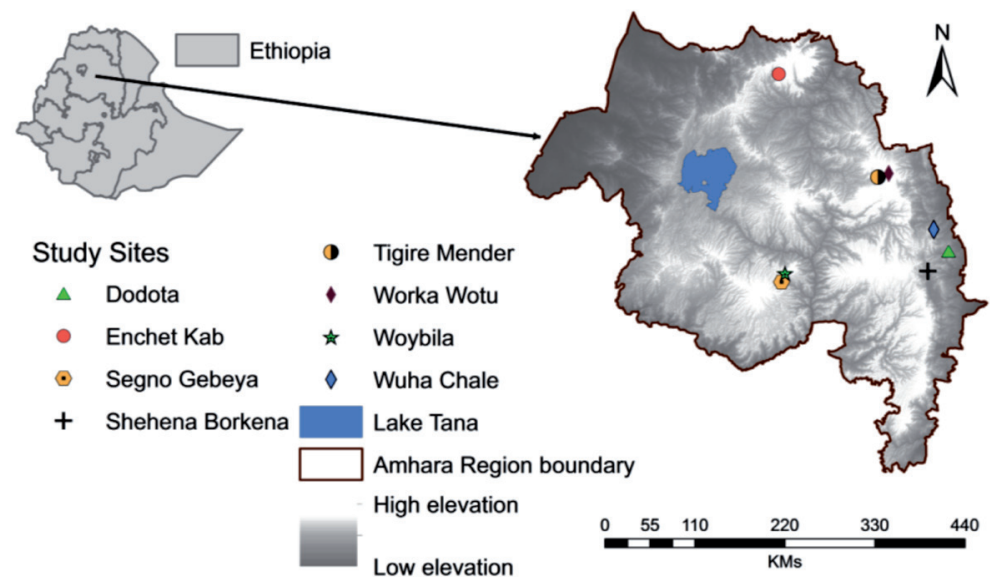

Figure 1. Location of the study sites. 


\subsection{Materials and methods}

Land use / land cover was determined using satellite imagery (SPOT; $5 \mathrm{~m}$ resolution). A topographic map 1:50 000 scale (EMA, 1987) was used to delineate the boundary of each sub-catchment. A Digital Elevation Model (ASTER DEM 30 m; 2009) was used to derive the elevation and slope characteristics of each sub-catchment. Sub-catchments outlet coordinates were taken in the field using a GPS device (Garmin GPS 60, 2 m accuracy) and measurement tape was used to measure channel dimensions in each of the sub-catchments.

\subsection{Methods}

In order to quantify the amount of sediment trapped by sediment storage dams (SSDs), to determine the sediment trapping efficacy of the SSDs and to calculate subcatchment sediment yield from the deposited sediment behind the dams the following methods were applied.

\subsubsection{Measuring trapped sediment in sediment storage dams}

To find multi-year data, SSDs with different ages (2-8 years old) in sub-catchments with different soil types, rainfall amounts and elevations were selected for this study. The amount of sediment trapped and stored behind each SSD was measured based on the geometric nature of the drainage channels, SSD dimensions and the surface area of the sediment using GPS and measuring tape. Some of the structures have trapezoidal shapes and others have rectangular shapes (see examples in Fig. 2).

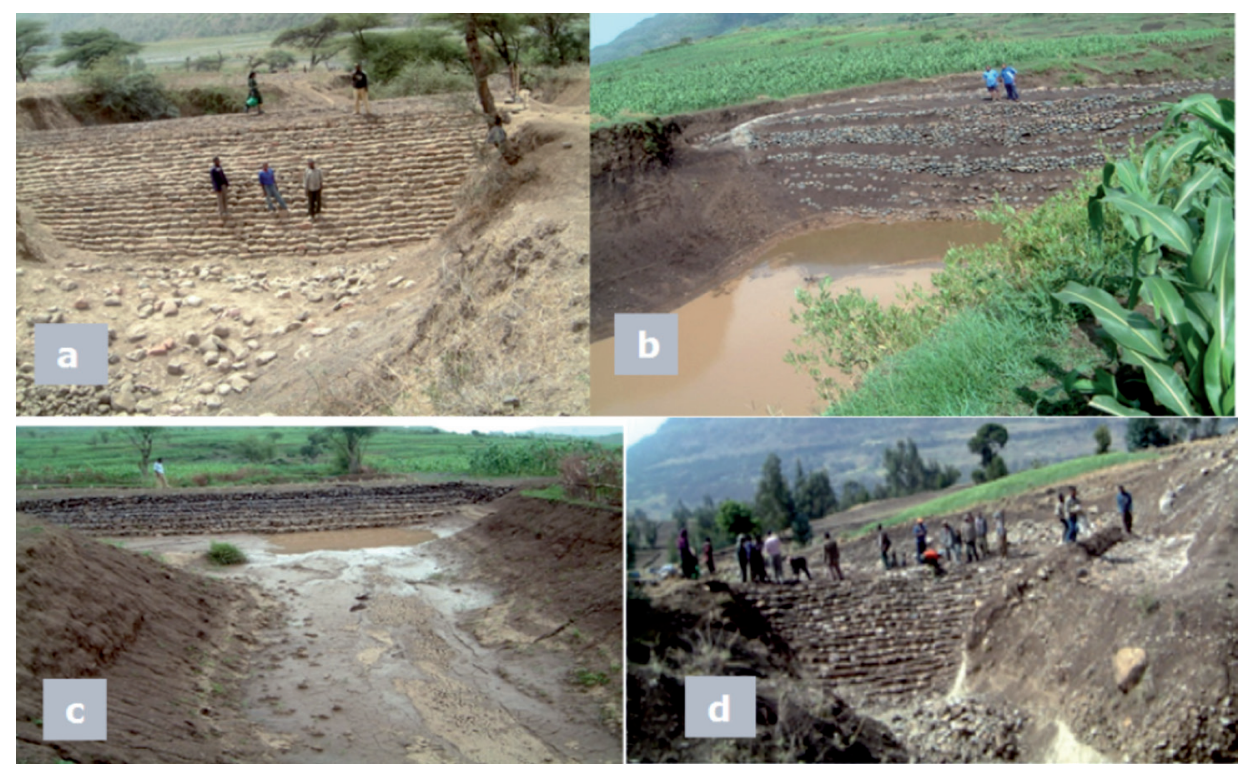

Figure 2. Examples of SSDs constructed in the Amhara region, Ethiopia (a) Delanta, (b) Kobo, (c) Bati and (d) Kutaber (Photos by Mulatie Mekonnen). 
To calculate the volume $\left(\mathrm{V} ; \mathrm{m}^{3}\right)$ of the sediment accumulated behind the trapezoidal shaped dams, the cross-sectional area $\left(\mathrm{A} ; \mathrm{m}^{2}\right)$ of the sedimentation times the length $(\mathrm{L}$; $\mathrm{m}$ ) from the SSD to the end of sedimentation upstream was calculated (Eq.1). The crosssectional area (A) of the trapped sediment is the average of the top and bottom widths (b2 and $\mathrm{b} 1 ; \mathrm{m})$ of the sediment times its height $(\mathrm{h} ; \mathrm{m})$ measured from the base of the dam to the sediment surface (Eq.2). For rectangular shape dams length times width times depth of the trapped sediment was used.

$$
\begin{aligned}
& V=A * L \\
& A=\frac{1}{2}(b 1+b 2) * h
\end{aligned}
$$

\subsubsection{Estimating the sediment trapping efficacy}

A proportion of the sediment entering into the SSDs, particularly the finest sediment fraction, is not trapped but passes the dam as suspended sediment. Therefore, the SSDs sediment trapping efficacy (STE) should be estimated to be able to include the un-trapped sediment into the overall sediment budget. STE is also an important indicator of the functioning of the dams in retaining and conserving sediments (Morgan, 2005; Sougnez et al., 2011). Two representative SSDs, one built from gabion to represent gabion SSDs and one built from stone to represent stone SSDs, which are not full of sediment yet, were evaluated for their STE. For that purpose, a total of 82 suspended sediment samples were collected from 21 rainfall events during the rainy season, 40 samples (20 inflows and 20 outflows) for the gabion SSD and 42 samples (21 inflows and 21 outflows) for the stone SSD. STE was calculated based on the inflow and outflow suspended sediment samples (Coyne et al., 1995; Verstraeten and Poesen, 2000) (Eq. 3).

$$
\text { STE }=\frac{\left(S_{\text {inflow }}-S_{\text {outflow }}\right)}{S_{\text {inflow }}}=1-\frac{S_{\text {outflow }}}{S_{\text {inflow }}} * 100
$$

where STE is sediment trapping efficacy (\%), $S_{\text {inflow }}$ is suspended sediment flowing into the $\operatorname{SSD}\left(\mathrm{g} \mathrm{l}^{-1}\right)$ and $S_{\text {outflow }}$ is suspended sediment flowing out of the $\operatorname{SSD}\left(\mathrm{g} \mathrm{l}^{-1}\right)$.

\subsubsection{Sediment yield measurement}

Sediment yield (SY) is the total sediment outflow from a catchment, to be measured at a point of reference and in a specified period of time either in absolute terms (e.g., $\mathrm{t} \mathrm{yr}^{-1}$ ) or in area specific terms (e.g., t ha- $\mathrm{yr}^{-1}$ ) (Vanoni, 1975; Verstraeten and Poesen, 2001). Catchment sediment yield can be estimated by measuring the retained sediment in dams, reservoirs, check dams and ponds constructed at the outlet of a catchment (White et al., 1997; Verstraeten and Poesen, 2002; Tamene et al., 2006b; Haregeweyn et al., 2008; Bellin et al., 2011; Sougnez et al., 2011; Baade et al., 2012). In this study, SY generated from the sub-catchments was estimated by measuring the deposited or trapped sediment behind the SSDs built at the outlets of the sub-catchments and estimating the un-trapped sediment using the STE (see section 2.3.2). The average annual SY transported from the 
catchments into the SSDs was calculated adding the trapped and un-trapped sediment and dividing it by the number of years involved to trap the sediment. Area specific sediment yield (SSY) was also calculated by dividing catchment sediment yield by catchment area.

\subsubsection{Deposited sediment density calculation}

To convert sediment volume, which was directly measured in the field to dry sediment mass and to calculate the catchments sediment yield in terms of mass, the density of the trapped sediment was estimated using the cylindrical core method (McKenzie et al., 2002). In the middle of the deposited sediment a $1.5 \mathrm{~m}$ deep pit was dugout vertically downward and sampling was done at three depths (upper, middle and lower) pushing the cylindrical core sampler $(5 \mathrm{~cm}$ diameter $* 7 \mathrm{~cm}$ long) into the side wall at the desired depth. The collected samples were oven dried at $105{ }^{\circ} \mathrm{C}$ in the laboratory and sediment density was calculated weighing the dried sediment and subtracting it from the wet sediment mass.

\section{Results}

\subsection{STE, trapped sediment and sediment yield}

The average sediment inflow, outflow and sediment trapped was $197.4 \mathrm{~g} \mathrm{l}^{-1}, 51.2$ $\mathrm{g} \mathrm{l}^{-1}$ and $146.2 \mathrm{~g} \mathrm{l}^{-1}$ at Segno Gebeya (gabion SSD) and $164.6 \mathrm{~g} \mathrm{l}^{-1}, 53.7 \mathrm{~g} \mathrm{l}^{-1}$ and 110.9 $\mathrm{g}^{-1}$ at Shehena Borkena (stone SSD), respectively. Based on these inflow and outflow suspended sediment data, STEs were calculated to be $74 \%$ and $67 \%$ for the gabion and stone SSDs, respectively. These efficacy values were used as a proxy for the SSDs of the other sub-catchments to be able to calculate the un-trapped sediment. Table 2 shows the values of measured trapped and estimated un-trapped sediment of each SSD. The average volume of sediment trapped and accumulated behind the eight SSDs within 2-8 years was found to be $5500 \mathrm{~m}^{3}$, but with high variation between sites (st. dev. of $4665 \mathrm{~m}^{3}$ ) reflecting differences in catchment size and soil erosion factors.

Table 2. Soil bulk density, volume and mass of sediment trapped and un-trapped by SSDs.

\begin{tabular}{|c|c|c|c|c|c|c|}
\hline Catchments & Type & $\begin{array}{c}\text { Trapped } \\
\text { sediment } \\
\left(\mathbf{m}^{\mathbf{3}}\right)\end{array}$ & $\begin{array}{c}\text { Bulk } \\
\text { density } \\
\left(\mathrm{g} \mathrm{cm}^{-3}\right)\end{array}$ & $\begin{array}{l}\text { Trapped } \\
\text { sediment } \\
\text { (t) }\end{array}$ & $\begin{array}{c}\text { Trapped } \\
\text { sediment } \\
\left(\mathrm{t} \mathrm{yr}^{-1}\right)\end{array}$ & $\begin{array}{l}\text { Un-trapped } \\
\text { sediment } \\
(t)\end{array}$ \\
\hline Segno Gebeya & Gabion & 3240 & 1.33 & 4309.2 & 2154.6 & 1120.4 \\
\hline Woybila & Stone & 15920 & 1.36 & 21651.2 & 4330.2 & 7144.9 \\
\hline Shehena Borkena & Stone & 6156 & 1.53 & 6418.7 & 1069.8 & 2118.2 \\
\hline Tigrie Mender & Stone & 1321 & 1.42 & 1875.8 & 468.9 & 619.0 \\
\hline Worka Wotu & Stone & 1516 & 1.18 & 1788.9 & 223.6 & 590.3 \\
\hline Dodota & Stone & 1085 & 1.31 & 1431.4 & 357.9 & 472.4 \\
\hline Enchet Kab & Stone & 7593 & 1.40 & 10630.2 & 2657.6 & 3508.0 \\
\hline Wuha Chale & Stone & 7167 & 1.38 & 9890.5 & 1412.9 & 3263.9 \\
\hline Average & & 5500 & 1.36 & 7249 & 1584.4 & 2355 \\
\hline St. dev & & 4665 & 0.09 & 6400 & 1502.2 & 2132 \\
\hline
\end{tabular}


Sediment bulk density values ranged from $1.33 \mathrm{~g} \mathrm{~cm}^{-3}$ in heavy clay sediment deposits to $1.53 \mathrm{~g} \mathrm{~cm}^{-3}$ in sandy loam dominated sediments. On average SSDs trapped about $1584 \mathrm{t}$ of sediment annually. Fig. 3 illustrates part of the sediment trapped and deposited behind the SSDs. Table 3 shows calculated annual sediment yield (SY) and area specific sediment yield (SSY) for all sub-catchments. SY and SSY show large variation between sub-catchments, ranging from 297-5759 $\mathrm{t}$ and 8.6-55 $\mathrm{t} \mathrm{ha}^{-1} \mathrm{yr}^{-1}$, respectively.

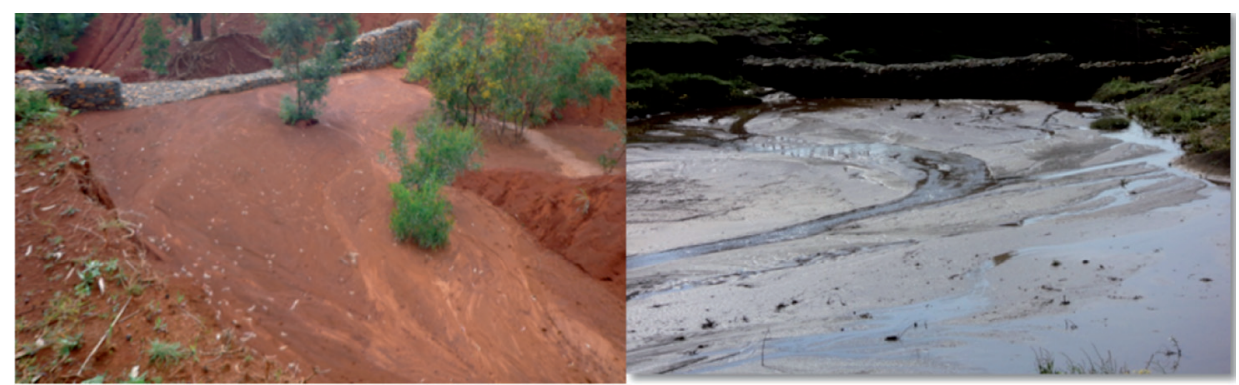

Figure 3. Example SSDs and trapped sediment at Segno Gebeya (left) and Enchet Kab (right) (Photo by Mulatie Mekonnen).

Table 3. Catchment area, SSDs age, sediment yield and area specific sediment yield of each catchment.

\begin{tabular}{|l|c|c|c|c|}
\hline \multicolumn{1}{|c|}{ Catchments } & Area (ha) & SSDs age (yr) & SY $\left(\mathbf{t ~ y r}^{-\mathbf{1}}\right)$ & SSY $\left(\mathbf{t ~ h a}^{-\mathbf{1}} \mathbf{~ y r}^{\mathbf{1}}\right)$ \\
\hline Segno Gebeya & 56.0 & 2 & 2714.8 & 48.5 \\
\hline Woybila & 104.5 & 5 & 5759.2 & 55.1 \\
\hline Shehena Borkena & 66.9 & 6 & 1422.8 & 21.3 \\
\hline Tigrie Mender & 41.8 & 4 & 623.7 & 14.9 \\
\hline Worka Wotu & 34.6 & 8 & 297.4 & 8.6 \\
\hline Dodota & 39.0 & 4 & 475.9 & 12.2 \\
\hline Enchet Kab & 84.3 & 4 & 3534.5 & 41.9 \\
\hline Wuha Chale & 71.8 & 7 & 1879.2 & 26.2 \\
\hline
\end{tabular}

\subsection{Cost of sediment storage dams}

The cost of building an SSD is an important factor affecting its implementation by small scale farmers and it's up-scaling to other users. The most important inputs such as stone, gabion and human labour were evaluated and their costs were estimated (Table 4). On average $8.74 €$ and $5.85 €$ are required to construct $1 \mathrm{~m}^{3}$ gabion and stone SSDs, respectively. This means that to trap $1 \mathrm{~m}^{3}$ sediment about $2.0 €$ for a gabion and from 0.4 to $1.7 €$ for a stone SSD was spent, which was calculated by dividing the dam costs by the volume of sediment trapped. The cost to trap $1 \mathrm{~m}^{3}$ sediment varies $(0.4$ to $1.7 €)$ although similar construction cost $(5.85 €)$ was financed for $1 \mathrm{~m}^{3}$ of all stone SSDs. This is because of difference in the amount of trapped sediment behind the constructed dams due to difference in shape of the 
reservoir in which sediment is deposited. The larger the reservoir behind the dam, the higher the amount of sediment trapped and the lower the cost per $\mathrm{m}^{3}$ of sediment and vice-versa. In all studied SSDs labour costs were found to be higher than material costs.

Table 4. Type, size and costs of sediment storage dams.

\begin{tabular}{|l|l|c|c|c|c|c|c|}
\hline \multicolumn{1}{|c|}{$\begin{array}{c}\text { SSD } \\
\text { sites }\end{array}$} & $\begin{array}{c}\text { SSD } \\
\text { type }\end{array}$ & $\begin{array}{c}\text { SSD size } \\
\left(\mathbf{m}^{\mathbf{3}}\right)\end{array}$ & $\begin{array}{c}\text { Stone } \\
\text { Cost }\end{array}$ & $\begin{array}{c}\text { Gabion } \\
\text { cost }\end{array}$ & $\begin{array}{c}\text { Labour } \\
\text { cost }\end{array}$ & $\begin{array}{c}\text { Total } \\
\text { cost }\end{array}$ & $\begin{array}{c}\text { Cost per } \mathbf{~ m}^{3} \\
\text { of sediment }\end{array}$ \\
\hline S.Gebeya & Gabion & 756 & 2063.9 & 2180 & 2358.7 & 6602.7 & 2.03 \\
\hline Woybila & Stone & 972 & 2653.6 & - & 3032.6 & 5686.2 & 0.36 \\
\hline S.Borkena & Stone & 483 & 1318.6 & - & 1507.0 & 2825.6 & 0.46 \\
\hline T.Mender & Stone & 325 & 887.3 & - & 1014.0 & 1901.3 & 1.44 \\
\hline Worka Wotu & Stone & 437 & 1193.0 & - & 1363.4 & 2556.4 & 1.68 \\
\hline Dodota & Stone & 306 & 835.4 & - & 954.7 & 1790.1 & 1.64 \\
\hline Enchet Kab & Stone & 529 & 1444.2 & - & 1650.5 & 3094.7 & 0.39 \\
\hline Wuha Chale & Stone & 617 & 1684.4 & - & 1925.0 & 3609.4 & 0.51 \\
\hline
\end{tabular}

Stone cost: $2.73 € \mathrm{~m}^{-3}$, Gabion cost: $16.77 €$ gabion $^{-1}$, Labour cost: $0.5 \mathrm{~m}^{3}$ person $^{-1} 1.56 €^{-1}$, Average costs are considered and all costs are in $€(1$ Ethiopian birr $=0.039 €)$

\section{Discussion}

\subsection{Sediment trapped by sediment storage dams and catchment sediment yield}

Rising rates of on-site soil erosion and off-site sedimentation in reservoirs and lakes emphasises the need to trap sediment along the sediment transfer pathways. Dam construction of both large and small sizes to trap sediment can reduce downstream sedimentation, flooding and other environmental problems. The world's registered

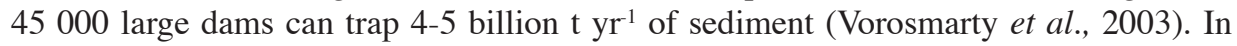
China more than 100000 smaller check dams trapped 21 billion $\mathrm{m}^{3}$ of sediment (Wang et al., 2011). Sougnez et al. (2011) estimated the sediment volume trapped by 20 check dams in southern Spain as ranging from 4-920 $\mathrm{m}^{3}$. In this study, sediment storage dams (SSDs) built at the outlets of eight small sub-catchments in the Amhara region in Ethiopia trapped a total of about $58 * 10^{3} \mathrm{t}\left(44^{*} 10^{3} \mathrm{~m}^{3}\right)$ sediment. On average these SSDs trapped about 1584 t of sediment annually.

In addition to reducing downstream reservoir sedimentation, SSDs contributed in conserving soil within the larger catchment and re-filling and stabilizing gullies. An SSD constructed at Woybila catchment within a gully, which is serving as a temporary drainage channel during the rainy seasons, trapped $\sim 22^{*} 10^{3}$ t of sediment and refilled a $8 \mathrm{~m}$ deep and $20 \mathrm{~m}$ wide gully in 5 years reducing slope gradient by $12 \%$ on average, which can slow down the speed of runoff and give time for infiltration and sediment deposition.

Sediment trapped and stored behind sediment trapping measures can be used to estimate sediment yield produced by upstream catchments (White et al., 1997; Verstraeten and Poesen, 2002; Bellin et al., 2011; Sougnez et al., 2011; Baade et al., 2012). In this 
study, the annual sediment yield of the investigated sub-catchments ranged from 8.6$55 \mathrm{t} \mathrm{ha}^{-1}$, which is in line with other findings in Ethiopia. For example, in northwest Ethiopia average annual sediment yield of $24.6 \mathrm{t} \mathrm{ha}^{-1}$ at Anjeni catchment (Setegn et al., 2010) and $13.6 \mathrm{t} \mathrm{ha}^{-1}$ at Angereb catchment (Amare, 2005) were reported. In the northern part of Ethiopia, the annual sediment yield of 10 catchments was estimated at 4-18 t ha $^{-1}$ (Haregeweyn et al., 2008) and 3.4-49 t ha-1 (Tamene et al., 2006a) for another 11 catchments in the same region.

Catchment size is an important controlling factor for catchment sediment yield (Morgan, 2005). For example, a direct relationship between area specific sediment yield and catchment area has been reported in different studies (de Vente et al., 2006; Haregeweyn et al., 2008) for small size catchments and a similar result was obtained in this study with $R^{2}=0.66$ (Fig. 4). This is due to limited deposition of the transported sediment within such small subcatchments. According to Wasson et al. (2002), about $80 \%$ of the sediment in the Argyle reservoir, Australia has come from gully and channel erosion, and sediment yield in three small size gullied catchments $(29,52$ and 510 ha) is at least one order of magnitude higher than that of un-gullied catchments (Armstrong and Mackenzie, 2002). In this study in the Segno Gebeya, Wuha Chale and Woybila sub-catchments foot paths, gullies and traditional ditches, and in the Enchet Kab and Shenena Borkena sub-catchments channel bank and gully erosions have some contribution for the estimated sediment yield.

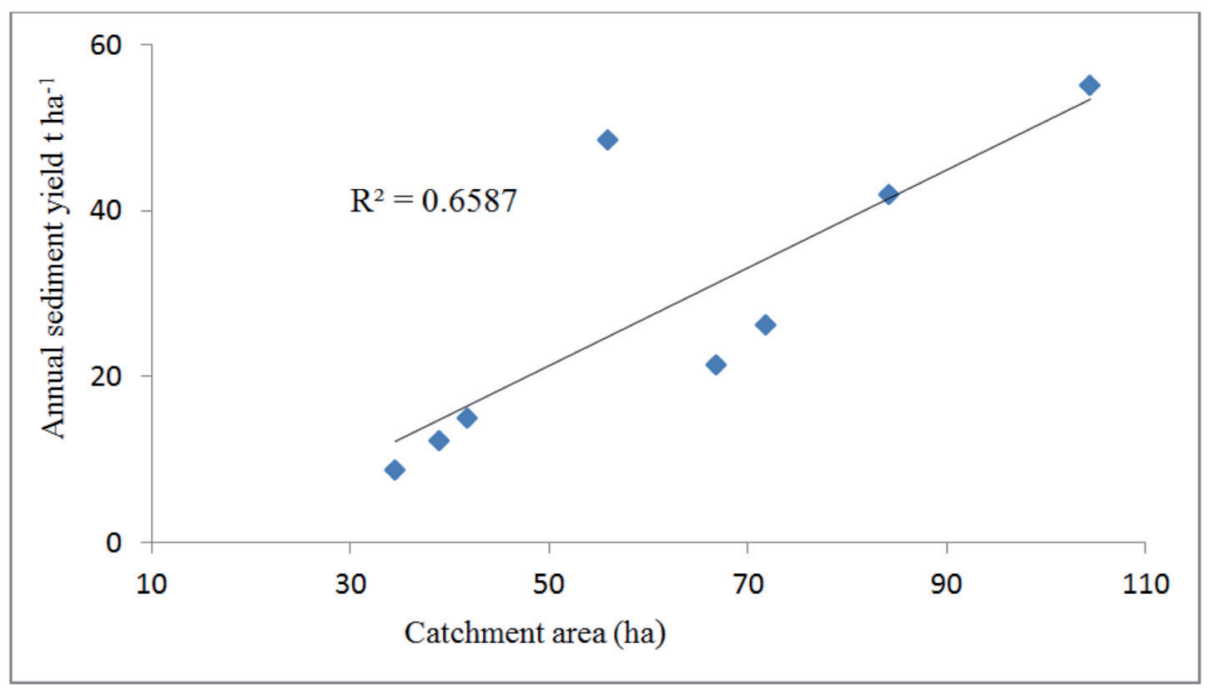

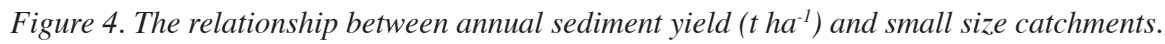

\subsection{Sediment trapping efficacy}

Sediment trapping efficacy is an important factor to evaluate the effectiveness of sediment trapping measures. Markle (2009) demonstrated the efficacy of a sediment pond in a Californian almond orchard, which trapped $80-84 \%$ of the sediment. According 
to Verstraeten and Poesen (2001), a typical pond of $1000 \mathrm{~m}^{3}$ with a catchment area of 25 ha in Belgium showed a short-term STE of 58-100\% and a long-term (33 yr) STE of $68 \%$. In northern Mississippi, the STE of small reservoirs was found to be $77 \%$ (Dendy and Cooper, 1984). In the northern part of Ethiopia Haregeweyn et al. (2006) estimated the STE of 10 reservoirs which ranged from 85-100\% and Tamene et al. (2006a) found STEs ranging from $86-97 \%$ in 11 catchments. In this study the STE of gabion and stone SSDs were found to be $74 \%$ and $67 \%$, respectively. This indicates that SSDs can trap and conserve up to $3 / 4$ of the inflow sediment coming from the upstream catchments in the form of surface erosion or concentrated through gullies, channel banks or foot path erosion and can be used as potential off-site sediment trapping measures.

The deposited sediment behind sediment trapping dams is an important indicator of soil loss in its upstream catchment provided the efficacy of the dams as a sediment trap is known (Morgan, 2005). For instance, the deposited sediment behind check dams was used to estimate soil loss from its upstream catchments (Bellin et al., 2011; Sougnez et al., 2011; Romero-Diaz et al., 2012). In this study soil loss in the upstream catchments was estimated at 8.6-55 $\mathrm{t} \mathrm{ha}^{-1} \mathrm{yr}^{-1}$. The soil loss value found in this study is within the same range of the study results conducted in northwest Ethiopia (Zegeye et al., 2010; Mekonnen and Melesse, 2011; Haile and Fetene, 2012). The total soil eroded within the catchments and transported into the SSDs was estimated by adding the trapped and un-trapped sediment. This method of estimating soil loss provides better results than for instance plot-scale measurement and catchment-scale river discharge sampling methods. This is because it represents the combined effects of soil erosion factors (soil type, land use/cover, slope, rainfall variability, etc.) at larger natural conditions, against plot-scale. Compared with data from suspended sediment concentrations, the data from sediment trapping dam survey incorporates materials transported as bed loads as well as suspended sediments which make the method more accurate.

Gullies and drainage channels are effective links to transfer runoff and sediment from the upper parts of a catchment to their outlets (Poesen et al., 2003) and serve as important sediment source and transfer pathways. The main objective of constructing SSDs within drainage channels is therefore to disconnect such paths and trap the sediment (MERET, 2008). Disconnecting sediment transfer paths through efficient sediment trapping measures could help to increase sediment deposition and reduce downstream sediment loads (Keesstra et al., 2009a; Baartman et al., 2013). In this study, SSDs were found to be important structural measures in disconnecting the sediment transfer paths and reducing the transport of sediment from upstream catchments to downstream water bodies (rivers, reservoirs or lakes).

Although SSDs played an important role in trapping sediments and reducing downstream sedimentation problems, they provide short term benefits (For example five out of the eight SSDs investigated have completely silted up in 4-8 years). After the dams are fully filled with sediment, the sediment transportation continues further downstream. To solve this problem sustainably, options are to (i) construct a series of dams within the drainage channel, which can increase the lifespan of each dam, and at the same time (ii) implementing on-site soil and water conservation measures (e.g. terraces and grass strips on farmlands, area closure on degraded lands, check dams inside gullies, 
etc.) to reduce erosion and trap the sediment within the sub-catchment before it reaches the SSDs. According to Mekonnen et al. (2014) the integration of on-site and off-site sediment trapping measures at the catchment scale, is believed to be the most effective in helping to increase the STE of the measures and thereby reducing sediment loads at the outlet of the catchment and ultimately reservoir siltation.

According to Nyssen et al. (2007) the increased erosive capacity and power of the low sediment-laden runoff can lead to scour and enhanced soil erosion. In this study, below the SSDs there were bottom and side scouring in some of the drainage channels, which might be due to the downstream effect of the clear water as a result of sediment accumulation behind the dams. Implementing vegetative measures, for example, planting grass and tree species and covering the bare land inside the temporary drainage channels where the SSDs have been built will be an option to minimize the problem.

\subsection{Cost required of construction of sediment storage dams}

In addition to sediment trapping efficacy (STE), the costs required to construct the sediment storage dam is an important factor affecting implementation of the technology at wider spatial scale and its adoption by farmers. The three most important inputs for SSD construction (human labour, gabion and stone) were assessed. Both stone and gabion SSDs are not affordable by the small scale farmers in northwest Ethiopia unless other alternatives are designed. For example: (i) a mass mobilization approach, which the Ethiopian government currently uses for soil and water conservation works. This forms a means to implement SSDs with free community participation to minimize at least the labour costs, which were found to be the largest part of the total construction costs; (ii) project support to cover at least the gabion (material) costs; and (iii) implementing SSDs where there is excess stone to reduce stone costs. These approaches could help to minimize the costs and up-scale the measures to wider spatial scales.

\section{Conclusion}

Sediment storage dams (SSDs), both gabion and stone, were found to be important off-site structural sediment trapping measures trapping sediment at the outlets of small sized catchments. The eight SSDs investigated, built from gabion and stone trapped a total of $\sim 44 * 10^{3} \mathrm{~m}^{3}$ or $\sim 58 * 10^{3}$ t of sediment within 2-8 years with sediment trapping efficacies of $74 \%$ and $67 \%$, respectively. In addition to evaluating the effectiveness of the dams, STE was used to estimate suspended sediment losses, and subsequently total (sub) catchment sediment yield. SSDs also reduce channel slope gradients and disconnect sediment transfer paths inside drainage channels in addition to re-filling gullies. The lifespan of the investigated SSDs was relatively short, i.e. to be more effective and use the SSDs sustainably they should be integrated with on-site soil conservation measures. Also, due to high costs, SSDs are not affordable for small scale farmers, alternatives to minimize the costs like mass mobilization, project support and implementing the dams in areas of excess construction materials should be considered to be able to upscale these measures. 


\section{Acknowledgements}

The authors would like to thank the NFP (Netherlands Fellowship Programme; CF Number: CF8569/2012) for its financial support and the Amhara National Regional State, Bureau of Agriculture for providing the first author with the opportunity to undertake his $\mathrm{PhD}$ research. We also would like to thank Wageningen University for providing advisory services and research facilities. We would also extend our thanks to the farmers, field data collectors and Agricultural Development Agents for their assistance during the field work. The comments of the anonymous reviewers were greatly appreciated.

\section{References}

Abedini, M., Md Said, M.A., Ahmad, F. 2012. Effectiveness of check dam to control soil erosion in a tropical catchment (The Ulu Kinta Basin). Catena 97, 63-70.

Amare, A. 2005. Study of sediment yield from the Watershed of Angereb reservoir. Master's Thesis, Department of Agricultural Engineering, Alemaya University, Ethiopia.

Amsalu, A., Stroosnijder, L., de Graaf, J. 2007. Long-term dynamics in land resource use and the driving forces in the Beressa watershed, highlands of Ethiopia. Journal of Environmental Management 83, 448-459.

Armstrong, J.L., Mackenzie, D.H. 2002. Sediment yields and turbidity records from small upland subcatchments in the Warragamba Dam catchment, southern New South Wales. Australian Journal of Soil Research 40, 557-579.

Baade, J., Franz, S., Reichel, A. 2012. Reservoir siltation and sediment yield in the Kruger National Park, South Africa: A first assessment. Land Degradation \& Development 23, 586-600.

Baartman, J.E.M., Masselink, R., Keesstra, S.D., Temme, A. 2013.Linking landscape morphological complexity and sediment connectivity. Earth Surface Processes and Landforms 38, 14571471.

Bellin, N., Vanacker, V., van Wesemael, B., Sole-Benet, A., Bakker, M.M. 2011. Natural and anthropogenic controls on soil erosion in the Internal Betic Cordillera (southeast Spain). Catena 87, 190-200.

Borin, M., Vianello, M., Morari, F., Zanin, G. 2005. Effectiveness of buffer strips in removing pollutants in runoff from a cultivated field in North-East Italy. Agriculture Ecosystems and Environment 105, 101-114.

Burylo, M., Rey, F., Bochet, E., Dutoit, T. 2012. Plant functional traits and species ability for sediment retention during concentrated flow erosion. Plant and Soil 353, 135-144.

Coyne, M.S., Gilfillen, R.A., Rhodes, R.W., Blevins, R.L. 1995. Soil and fecal coliform trapping by grass filter strips during simulated rain. Journal of Soil and Water Conservation 50, 405408.

De Vente, J., Poesen, J., Bazzoffi, P., Van Rompaey, A., Verstraeten, G. 2006. Predicting catchment sediment yield in Mediterranean environments: the importance of sediment sources and connectivity in Italian drainage basins. Earth Surface Processes and Landforms 31, 1017 1034.

Dendy, F., Cooper, C. 1984. Sediment trap efficiency of a small reservoir. Journal of Soil and Water Conservation 39, 278-280.

EMA. 1987. Ethiopian Mapping Agency. Field survey by EMA. Air photography 1:50 000 scale by SWEDSURVEY, Addis Ababa, Ethiopia. 
Fiener, P., Auerswald, K.,Weigand, S. 2005. Managing erosion and water quality in agricultural watersheds by small detention ponds. Agriculture, Ecosystems and Environment 110, 132142.

Fisseha, G., Gebrekidan, H., Kibret, K., Bedadi, B., Yitaferu, B. 2011. Participatory Development of Soil Conservation Measures at the Debre-Mewi Watershed in the Upper Catchment of the Blue Nile Basin, Northwest Ethiopia. Journal of Biodiversity and Environmental Sciences (JBES) 1, 199-213.

Haile, G.W., Fetene, M. 2012. Assessment of soil erosion hazard in kilie catchment, East Shoa, Ethiopia. Land Degradation \& Development 23, 293-306.

Haregeweyn, N., Poesen, J., Nyssen, J., De Wit, J., Haile, M., Govers, G., Deckers, S. 2006. Reservoirs in Tigray (Northern Ethiopia): Characteristics and sediment deposition problems. Land Degradation \& Development 17, 211-230.

Haregeweyn, N., Poesen, J., Nyssen, J., Govers, G., Verstraeten, G., de Vente, J., Deckers, J., Moeyersons, J., Haile, M. 2008. Sediment yield variability in Northern Ethiopia: A quantitative analysis of its controlling factors. Catena 75, 65-76.

Hughes, A.O., Prosser, P.I. 2012. Gully erosion prediction across a large region: Murray-Darling Basin, Australia. Soil Research 50, 267-277.

Kebede, W. 2012. Watershed Manual: An Option to Sustain Dam and Reservoir Functions in Ethiopia. Journal of Environmental Sciences and Technology 5, 262-273.

Keesstra, S.D. 2007. Impact of natural reforestation on floodplain sedimentation in the Dragonja basin, SW Slovenia. Earth Surface Processes and Landforms 32, 49-65.

Keesstra, S.D., Bruijnzeel, L.A., van Huissteden, J. 2009a. Meso-scale catchment sediment budgets: combining field surveys and modeling in the Dragonja catchment, southwest Slovenia. Earth Surface Processes and Landforms 34, 1547-1561.

Keesstra, S.D., van Dam, O., Verstraeten, G., van Huissteden, J. 2009b. Changing sediment generation due to natural reforestation in the Dragonja catchment, SW Slovenia. Catena 78, 60-71.

Knight, K.W., Schultz, R.C., Mabry, C.M., Isenhart, T.M. 2010. Ability of remnant riparian forests, with and without grass filters, to buffer concentrated surface runoff. Journal of the American Water Resources Association 46, 311-322.

Lakel, W.A., III, Aust, W.M., Holding, M.C., Dolloff, C.A., Keyser, P., Feldt, R. 2010. Sediment trapping by streamside management zones of various widths after forest harvest and site preparation. Forest Science 56, 541-551.

Leguédois, S., Ellis, T.W., Hairsine, P.B., Tongway, D.J. 2008. Sediment trapping by a tree belt: Processes and consequences for sediment delivery. Hydrological Processes 22, 3523-3534.

Markle, J. 2009. Efficacy of settlement ponds for reducing pyrethroid runoff in almond orchards. Modesto, CA: Almond Board of California. Final research report 2008-2009, 1-24.

McCaleb, M.M., McLaughlin, R.A. 2008. Sediment trapping by five different sediment detention devices on conservation sites Transactions of the ASABE 51, 1613-1621.

McKenzie, N., Coughlan, K.J., Cresswell, H. 2002. Soil Physical Measurement and Interpretation For Land Evaluation. CSIRO Publishing: Collingwood, Victoria.

Mekonnen, M., Keesstra, S.D., Baartman, J.E.M., Stroosnijder, L., Maroulis, J. 2014. Soil Conservation Through Sediment Trapping: A review. Land Degradation \& Development DOI, 10.1002 l-1dr.2308.

Mekonnen, M., Melesse, A.M. 2011. Soil Erosion Mapping and Hotspot area identification using GIS and Remote Sensing in Northwest Ethiopian Highlands, Near lake Tana. Nile River Basin; hydrology, climate \& water use, Springer, 207-224. 
MERET. 2008. MERET NEWS: A quarterly newsletter published by the Ministry of Agriculture and Rural Development, MERET, Project coordination office, Bahir Dar, Ethiopia. Report No 5, 9-10.

Middelkoop, H., Erkens, G., van der Perk, M. 2010. The Rhine delta-a record of sediment trapping over time scales from millennia to decades. Journal of Soils and Sediments 10(4), 628-639.

Morgan, R.P.C. 2005. Soil erosion and conservation, 3rd ed. National Soil Resource Institute, Cranfield University, Blackwell, London.

Nyssen J, Descheemaeker K, Haregeweyn N, Haile M, Deckers J, Poesen J. 2007. Lessons learnt from 10 years research on SWC in Tigray. Tigray Livelihood Papers No. 7. Zala-Daget Project, Mekelle University, K.U.Leuven, Tigray BOARD. ISBN 978-90-8826-027-8; 53.

Nyssen, J., Poesen, J., Moeyersons, j., Mitiku, H., Deckers, J. 2008. Dynamics of soil erosion rates and controlling factors in the Northern Ethiopian Highlands - towards a sediment budget. Earth Surface Processes and Landforms 33, 695-711.

Poesen, J., Nachtergaele, J., Verstraeten, G., Valentin, C. 2003. Gully erosion and environmental change: importance and research needs. Catena 50, 91-133.

Ritsema, C.J. 2003. Introduction: soil erosion and participatory land use planning on the Loess Plateau in China. Catena 54, 1-5.

Romero-Díaz, A., Marin-Sanleandro, P., Ortiz-Silla, R. 2012. Loss of soil fertility estimated from sediment trapped in check dams. South-eastern Spain. Catena 99, 42-53.

Schoonover, J.E., Williard, K.W.J., Zaczek, J.J., Mangun, J.C., Carver, A.D. 2006. Agricultural sediment reduction by giant cane and forest riparian buffers. Water Air and Soil Pollution 169, 303-315.

Setegn, S.G., Dargahi, B., Srinivasan, R., Melesse, A.M. 2010. Modelling of sediment yield from Anjeni gauged watershed, Ethiopia using SWAT Model. Journal of the American Water Resources Association 46, 514-526.

Sougnez, N., van Wesemael, B., Vanacker, V. 2011. Low erosion rates measured for steep, sparsely vegetated catchments in southeast Spain. Catena 84, 1-11.

Tamene, L., Park, S., Dikau, R., Vlek, P. 2006a. Reservoir siltation in the semi-arid highlands of northern Ethiopcatchment area relationship and a semi-quantitative approach for predicting sediment yield. Earth Surface Processes and Landforms 31(11), 1364-1383.

Tamene, L., Park, S.J., Dikau, R., Vlek, P.L.G. 2006b. Analysis of factors determining sediment yield variability in the highlands of northern Ethiopia. Geomorphology 76, 76-91.

Vanoni, V.A. 1975. Sedimentation Engineering. ASCE Manuals and Reports on Engineering Practices. No 54. ASCE.

Verstraeten, G., Poesen, J. 2000. Estimating trap efficiency of small reservoirs and ponds: methods and implications for the assessment of sediment yield. Progress in Physical Geography 24, 219-251.

Verstraeten, G., Poesen, J. 2001. Factors controlling sediment yield from small intensively cultivated catchments in a temperate humid climate. Geomorphology 40, 123-144.

Verstraeten, G., Poesen, J. 2002. Regional scale variability in sediment and nutrient delivery from small agricultural watersheds. Journal of Environmental Quality 31(3), 870-879.

Vorosmarty, C.J., Meybeck, M., Fekete, B., Sharma, K., Green, P., Syvitski, J.P.M. 2003. Anthropogenic sediment retention: major global impact from registered river impoundments. Global and Planetary Change 39, 169-190.

Walling, D.E. 2006. Human impact on land-ocean sediment transfer by the world's rivers. Geomorphology 79, 192-216.

Wang, Y., Fu, B., Chen, L., Lü, Y., Gao, Y. 2011. Check dam in the loess plateau of China: Engineering for environmental services and food security. Environmental Science and Technology 45(24), 10298-10299. 
Ward, J.M., Jackson, C.R. 2004. Sediment trapping within forestry streamside management zones: Georgia Piedmont, USA. Journal of the American Water Resources Association 40(6), 14211431.

Wasson, R.J., Caitcheon, G., Murray, A.S., McCulloch, M., Quade, J. 2002. Sourcing sediment using multiple tracers catchment of Lake Argyle, northwestern Australia. Environmental Management 29 (5), 634-646.

WBISPP. 2002. Manual for Woody Biomass Inventory and Strategic Planning Project, Ministry of Agriculture, Addis Ababa, Ethiopia.

White, P., Butcher, D., Labadz, J. 1997. Reservoir sedimentation and catchment sediment yield in the Strines catchment, UK. Physics and Chemistry of the Earth 22, 321-328.

Zegeye, A.D., Steenhuis, T.S., Blake, R.W., Kidnau, S., Collick, A.S., Dadgari, F. 2010. Assessment of soil erosion processes and farmer perception of land conservation in Debre Mewi watershed near lake Tana, Ethiopia. Ecohydrology and Hydrobiology 0, 297-306.

Zeleke, G. 2000. Landscape dynamics and soil erosion process modeling in the North-Western Ethiopian Highlands. African Studies Series A 16, Geographica Bernensia Berne, Switzerland.

Zhang, G.-H., Liu, G.-B., Wang, G.-L. 2010. Effects of Caragana Korshinskii Kom cover on runoff, sediment yield and nitrogen loss. International Journal of Sediment Research 25, 245-257. 